Practicing Transnationalism 
THIS PAGE INTENTIONALLY LEFT BLANK 


\section{Practicing Transnationalism}

American Studies in the Middle East

EDITED BY EILEEN T. LUNDY

AND EDWARD J. LUNDY

University of Texas Press 4 Austin 
Copyright (C) 2016 by the University of Texas Press

All rights reserved

Printed in the United States of America

First edition, 2016

Requests for permission to reproduce material from this work should be sent to:

Permissions

University of Texas Press

P.O. Box 7819

Austin, TX 78713-7819

http://utpress.utexas.edu/index.php/rp-form

@ The paper used in this book meets the minimum requirements of

ANSI/NISO Z39.48-1992 (R1997) (Permanence of Paper).

\section{Library of Congress Cataloging-in-Publication Data}

Names: Lundy, Eileen T., editor. | Lundy, Edward J., editor.

Title: Practicing transnationalism : American studies in the Middle East / edited by Eileen T. Lundy and Edward J. Lundy.

Description: First edition. | Austin : University of Texas Press, 2016. | Includes bibliographical references and index.

Identifiers: LCCN 2016004934 | ISBN 978-1-4773-0928-5 (cloth : alk. paper) | ISBN 978-1-4773-1073-1 (pbk. : alk. paper) | ISBN 978-1-4773-0929-2

(library e-book) | ISBN 978-1-4773-0930-8 (nonlibrary e-book)

Subjects: LCSH: United States—Civilization—Study and teaching-Middle East. | United States—Study and teaching (Higher)—Middle East. |

Education, Higher-Middle East. | Educational exchanges—Middle East. | Transnationalism.

Classification: LCC E175.8 .P735 2016 | DDC 973.071/1—dc23

LC record available at http://lccn.loc.gov/2016004934

doi:10.7560/309285 